\section{Effective Bioassays for Evaluating Boxwood Blight Susceptibility Using Detached Stem Inoculations}

\author{
Yonghong Guo and Richard T. Olsen \\ U.S. Department of Agriculture/Agricultural Research Service, U.S. National \\ Arboretum-Floral and Nursery Plants Research Unit, 10300 Baltimore \\ Avenue, Beltsville, MD 20705

\section{Matthew Kramer} \\ U.S. Department of Agriculture/Agricultural Research Service, Biometrical \\ Consulting Service, 10300 Baltimore Avenue, Beltsville, MD 20705
}

\section{Margaret Pooler ${ }^{1}$}

U.S. Department of Agriculture/Agricultural Research Service, U.S. National Arboretum-Floral and Nursery Plants Research Unit, 10300 Baltimore Avenue, Beltsville, MD 20705

Additional index words. Buxus, Calonectria pseudonaviculata, Cylindrocladium buxicola, leaf inoculation, detached branch assay, resistance breeding

\begin{abstract}
Two simple and rapid in vitro bioassays using detached stems were developed for evaluating the susceptibility of boxwood genotypes to the blight disease caused by Calonectria pseudonaviculata (Crous et al.) L. Lombard et al. Individual leaves were inoculated on detached stems or entire detached stems were sprayed to assess susceptibility. Both assay systems were optimized for inoculum concentration and disease rating time. The assay methods described here require minimal plant material and inoculum, especially the leaf inoculation assay, which uses as few as six leaves per stem and 500 spores per leaf for inoculation. The stem spray inoculation produced less variable results and was easier for quantifying susceptibility but required more inoculum than the leaf inoculation assay. No differences between the assays were found for the cultivars tested. The leaf inoculation assay is best used when limited plant material or inoculum is available; the spray inoculation of detached stems is suitable when larger plants are available.
\end{abstract}

Boxwood (Buxus L. spp.) are slow-growing evergreen shrubs and small trees. They are commonly grown as hedges and for topiary and are commercially important components of managed landscapes. Over 13 million boxwood plants are sold in the United States each year with an annual market value of over \$100 million (USDA-NASS, 2010). Boxwood

Received for publication 17 Sept. 2014. Accepted for publication 13 Dec. 2014.

Research presented in this article was funded in part through the Floral and Nursery Research Initiative.

The mention of trade names or commercial products in this article is solely for the purpose of providing specific information and does not imply recommendations or endorsement by the U.S. Department of Agriculture. The USDA is an equal opportunity employer.

We thank Dr. Dimitre Mollov, USDA-ARS National Genetic Resources Laboratory, Beltsville, $\mathrm{MD}$, for reviewing the manuscript; and Dr. Joanne Crouch, USDA-ARS Systematic Mycology and Microbiology Laboratory, Beltsville, MD, for providing fungal isolates and laboratory facilities used in this study.

${ }^{1}$ To whom reprint requests should be addressed; e-mail Margaret.Pooler@ars.usda.gov. blight, caused by the fungus Calonectria pseudonaviculata (Crous et al.) L. Lombard et al. (syn. Cylindrocladium pseudonaviculatum, $C$. buxicola), is a destructive leaf-drop and stem-lesion disease and is of significant concern throughout Europe, especially the United Kingdom, since the early 1990s (Henricot and Culham, 2002). The disease was recently discovered in North America, first confirmed in Nov. 2011 in Connecticut and North Carolina (Ivors et al., 2012). It has now been confirmed in 14 states (Alabama, Connecticut, Delaware, Georgia, Massachusetts, Maryland, North Carolina, New Jersey, New York, Ohio, Oregon, Pennsylvania, Rhode Island, Virginia) and three Canadian provinces (British Columbia, Ontario, Quebec) (Elmhirst and Auxier, 2013; Hagan and Conner, 2013; Malapi-Wight et al., 2013; Williams-Woodward, 2014).

Fungicidal management of the pathogen has been effective (Henricot et al., 2008; LaMondia, 2014); however, developing blight-resistant cultivars is the preferred long-term management strategy for boxwood blight. The genus Buxus contains $\approx 90$ species with more than 350 cultivars representing diverse forms, sizes, and foliage characteristics (Batdorf, 2004). The American boxwood (B. sempervirens) and the English boxwood
(B. sempervirens 'Suffruticosa') are two of the most widely grown types in the United States (Batdorf, 2005). Identifying which of this diverse material is most tolerant to boxwood blight is necessary for beginning a breeding program to develop blight-resistant cultivars and the screening of potentially thousands of seedlings from controlled hybridizations. Effective screening of whole plants has been reported (Ganci et al., 2013), but it requires space for multiple replications of large containerized plants or in-ground assays with obvious disease containment issues to manage. The objective of this study was to develop simple and rapid assays using detached stems and two inoculation methods to screen plants for resistance to boxwood blight.

\section{Materials and Methods}

Plant material. All plant material was taken from the National Boxwood Collection at the USDA-ARS U.S. National Arboretum in Washington, DC (Table 1). The terminal 20 to $30 \mathrm{~cm}$ of stems were harvested from boxwood plants (a single plant for each taxon indicated), wrapped in moistened paper towels at the branch base, and stored in plastic bags at $4{ }^{\circ} \mathrm{C}$ for up to 1 week until use.

Fungal isolates and inoculation parameters. Ten $C$. pseudonaviculata isolates were provided by JoAnne Crouch (USDA-ARS Systematic Mycology and Microbiology Laboratory, Beltsville, MD): eight from collections made in the United States (CpsCT3, CpsCT7, CpsCT9, CpsCT14, CpsCT15, CpsL2, and CpsS1, all from Connecticut; ODA\#1 from Oregon) and two international collections (CBS114417, from the United Kingdom; ICMP17495, from New Zealand). Fungal cultures were grown on potato dextrose agar (PDA) medium in an incubator at $23{ }^{\circ} \mathrm{C}$ with $24 \mathrm{~h}$ light. Mycelium on the surface of the PDA was flattened and scraped with a sterile spatula to stimulate sporulation (K. Ivors, personal communication). The scraped plates were returned to the incubator for 3 to $5 \mathrm{~d}$. Conidia were collected by rinsing the culture surface with sterile water. The resultant spore solution was filtered with two layers of cheesecloth to remove any culture debris, and then spores were counted with a hemocytometer. To prepare inoculum,

Table 1. Boxwood (Buxus) taxa used to investigate Calonectria pseudonaviculata inoculation parameters and susceptibility to disease.

\begin{tabular}{|c|c|}
\hline Accession & Taxon \\
\hline NA 36672-L & B. harlandii Hance \\
\hline NA $26391-\mathrm{H}$ & $\begin{array}{l}\text { B. sempervirens L. } \\
\text { 'Handsworthiensis' }\end{array}$ \\
\hline NA $29703-\mathrm{H}$ & $\begin{array}{l}\text { B. sempervirens } \mathrm{L} \text {. } \\
\text { 'Suffruticosa' }\end{array}$ \\
\hline NA $6395-55$ & $\begin{array}{l}\text { B. sempervirens L. } \\
\text { 'Vardar Valley' }\end{array}$ \\
\hline NA 35486-H & $\begin{array}{l}\text { B. sinica var. insularis } \\
\text { (Nakai) M. Cheng }\end{array}$ \\
\hline NA $51898-\mathrm{J}$ & $\begin{array}{l}\text { B. sinica var. insularis (Nakai) } \\
\text { M. Cheng 'Pincushion' }\end{array}$ \\
\hline
\end{tabular}

HortScience Vol. 50(2) February 2015 
a mixture of conidia collected from plates of the 10 isolates was used to inoculate detached stems from $B$. sempervirens 'Suffruticosa', a known susceptible cultivar. After 7 to $10 \mathrm{~d}$, when conidia appeared on the underside of leaves, the spores were washed from the infected leaves with sterile distilled water, and the resulting spore suspensions were filtered through two layers of cheesecloth. Conidia concentration was determined by hemocytometer counts.

We conducted preliminary experiments to determine the number of days post-inoculation (dpi) needed to rate disease symptoms. We used stems of the highly susceptible $B$. sempervirens 'Suffruticosa' and those of the less susceptible 'Varder Valley' inoculated with 20,000 spores $/ \mathrm{mL}$ (Fig. 1). It appeared that little change occurred in the proportion of diseased leaf area expressed as a logit $=\log$ $[p /(100-p)]$, where $p=$ percent, to help stabilize variances $\}$ after $7 \mathrm{~d}$. Data for assays were therefore taken at $7 \mathrm{dpi}$.

Leaf surface assay. Preliminary trials were conducted to determine whether inoculation of the adaxial or abaxial leaf surface affected symptom expression. Explants from six genotypes (Table 1) were inoculated on the adaxial or abaxial leaf surface using either leaf inoculations (1000 spores per leaf) or detached stem spray inoculations $(40,000$ spores $/ \mathrm{mL}$ ) following the methods described below. Three explants were used for each treatment.

Leaf inoculation assay. Terminal stems containing at least six leaves were harvested from each plant. Leaves were pre-wetted by immersing in tap water, and the extra water was removed with gentle shaking. Before the leaves dried, a $5-\mu \mathrm{L}$ droplet containing 0 , $100,200,300,400,500,750$, or 1000 spores in suspension was pipetted onto the abaxial (lower) surface of each leaf. Three stems (each with at least six leaves) were inoculated for each treatment. The stems with inoculated

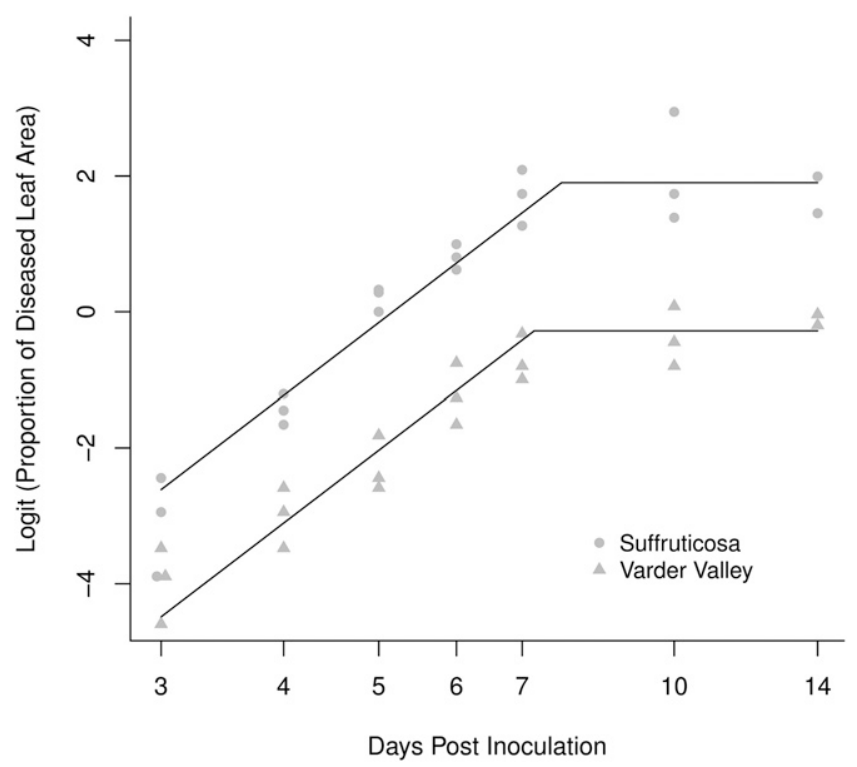

Fig. 1. Boxwood blight symptom development on inoculated leaves of Buxus sempervirens 'Suffruticosa' and 'Vardar Valley', expressed as the logit of the proportion (p) of diseased leaf area measured at 3, 4, $5,6,7,10$. and $14 \mathrm{~d}$ (depicted on the log scale) post-inoculation (dpi). Individual leaves were inoculated with a $5-\mu \mathrm{L}$ drop containing 500 conidia. On these scales, the logit (p) over the first $7 \mathrm{~d}$ satisfies a linear regression equation with intercepts, but not slopes, differing for the two genotypes, intersecting with means fit to days 7, 10, and 14 dpi. Note that the intersection of these lines occurs near Day 7.

Table 2. Mean percentage ( $\pm 1 \mathrm{SD}$ ) of leaves with symptoms after inoculating the adaxial (upper) or abaxial (lower) leaf surfaces of different genotypes for both the leaf inoculation and stem spray inoculation methods. $^{\mathrm{z}}$

\begin{tabular}{|c|c|c|c|c|}
\hline \multirow[b]{2}{*}{ Genotype } & \multicolumn{2}{|c|}{ Leaf inoculation } & \multicolumn{2}{|c|}{ Stem spray inoculation } \\
\hline & Adaxial & Abaxial & Adaxial & Abaxial \\
\hline Handsworthiensis & $6 \pm 5.0$ & $97 \pm 4.6$ & $14 \pm 12.4$ & $94 \pm 3.1$ \\
\hline Harlandii & $17 \pm 6.0$ & $92 \pm 7.6$ & $7 \pm 4.8$ & $71 \pm 4.2$ \\
\hline Insularis & $17 \pm 5.9$ & $88 \pm 0.8$ & $12 \pm 14.2$ & $71 \pm 10.3$ \\
\hline Pincushion & $13 \pm 2.9$ & $92 \pm 14.4$ & $13 \pm 7.6$ & $86 \pm 7.4$ \\
\hline Suffruticosa & $64 \pm 8.4$ & $100 \pm 0.0$ & $32 \pm 12.2$ & $95 \pm 5.0$ \\
\hline Vardar Valley & $13 \pm 12.5$ & $97 \pm 4.6$ & $8 \pm 7.4$ & $41 \pm 7.2$ \\
\hline
\end{tabular}

${ }^{\mathrm{z}}$ Inoculations of different genotypes were performed at different times; therefore, comparison of genotypes was not made.
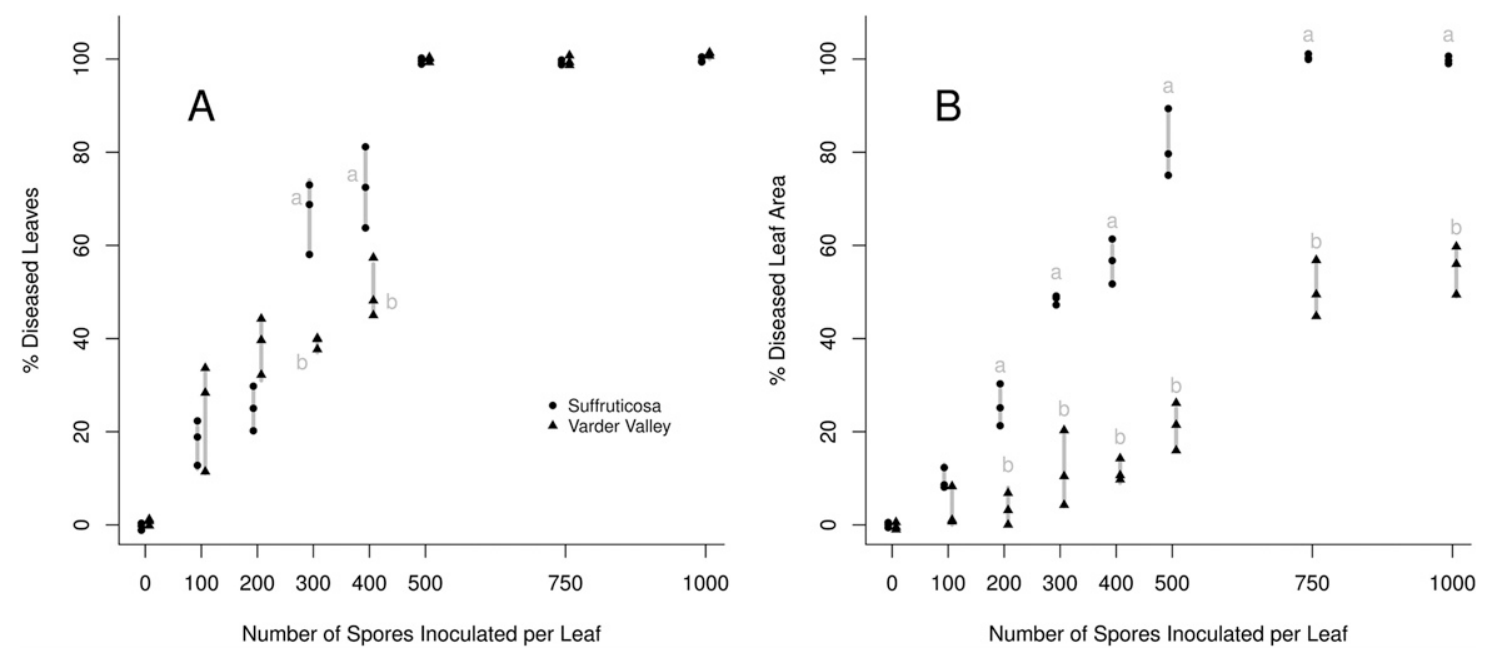

Fig. 2. Boxwood blight symptom development on Buxus sempervirens 'Suffruticosa' and 'Vardar Valley' inoculated with increasing spore concentrations, from 0 to 1000 conidia per 5- $\mu \mathrm{L}$ drop, expressed as (A) percent symptomatic leaves and (B) percent diseased leaf area. Means separation letters (a, b) are given if genotypes differed at that concentration. Data are shown as black points over their range (gray lines). Points that were close together were offset slightly to improve their visibility. 
leaves were placed in a Magenta box containing $\approx 20 \mathrm{~mL}$ of $1.5 \%$ water agar and placed in an incubator at $23{ }^{\circ} \mathrm{C}$ with continuous light. Disease symptoms were monitored 3 to 14 dpi, and digital images of leaves were recorded. The infected and total leaf area was measured using Assess 2.0, the Image Analysis Software for Plant Disease Quantification (APS Press, St. Paul, MN). These numbers were then used to calculate the percent diseased area per leaf.

Detached stem spray inoculation assay. Terminal stems with at least 30 leaves were used for the spray inoculation assay. Inoculum concentration was determined based on hemocytometer counts, and inoculation solution containing $0,5 \times 10^{3}, 1 \times 10^{4}, 2 \times 10^{4}, 3 \times$ $10^{4}, 4 \times 10^{4}$, or $5 \times 10^{4}$ spores $/ \mathrm{mL}$ was placed in a mist sprayer. Detached stems were sprayed until runoff on both the adaxial and abaxial leaf surfaces. Three or four stems were used for each treatment. The inoculated stems were placed in Magenta boxes and maintained in an incubator as described in the leaf inoculation assay. The disease rating was expressed as the percentage of fallen leaves compared with total leaves on the original stem.

Statistics. Percent data were analyzed on the logit scale $\{\log [p /(100-p)]$, where $p=$ percent $\}$, which helps stabilize variances. Values of $0 \%(-\infty$ on the logit scale) and $100 \%(+\infty$ on the logit scale) were either not used in analyses or had a small amount of noise added to (or subtracted from) them to move them slightly away from $0 \%$ or $100 \%$. Linear statistical models were fit using $\mathrm{R}$ software (R Core Team 2014); multiple comparison adjustments on means comparisons were conducted using the multcomp package (Hothorn et al., 2008) using the default single-step adjustment method. The nlme package (Pinheiro et al., 2014) was used to fit a linear model for groups with unequal variances. All figures but one are depicted on the original percent scale for ease of interpretation.

\section{Results and Discussion}

Because C. pseudonaviculata is spread by water droplets, often by splashing, and sporulation occurs on the underside of the leaves (Douglas, 2012), we hypothesized that symptom expression could be different depending on which leaf surface was inoculated. Results indicate that for the leaf inoculation and stem spray inoculation, symptom expression is greater and more consistent if the abaxial surface of leaves is inoculated rather than the adaxial surface (Table 2). This may be a result of greater stomatal densities on the abaxial surface as revealed by microscopic examination of leaves in our laboratory (unpublished data). This result contrasts somewhat with that of Gehesquiere (2014), who found no effect of leaf surface on the retention and germination of conidia. However, we were studying disease symptom expression after inoculating only one leaf surface, whereas Gehesquiere examined fungal retention and germination after inoculating both surfaces.
Based on our results, we therefore inoculated the abaxial surface of leaves in our leaf inoculation assay but sprayed the entire leaf in the stem spray inoculation assay as a result of the difficulty of controlling spray inoculations strictly to one leaf surface.

We used a mixture of 10 fungal isolates to prepare the inoculum for these studies, because both resistance among cultivars and virulence among fungal isolates likely vary. Studies are currently underway in our laboratory to examine host $\times$ pathogen interactions to reduce the number of fungal isolates for future resistance screening assays, better mimicking typical pathogen exposure.

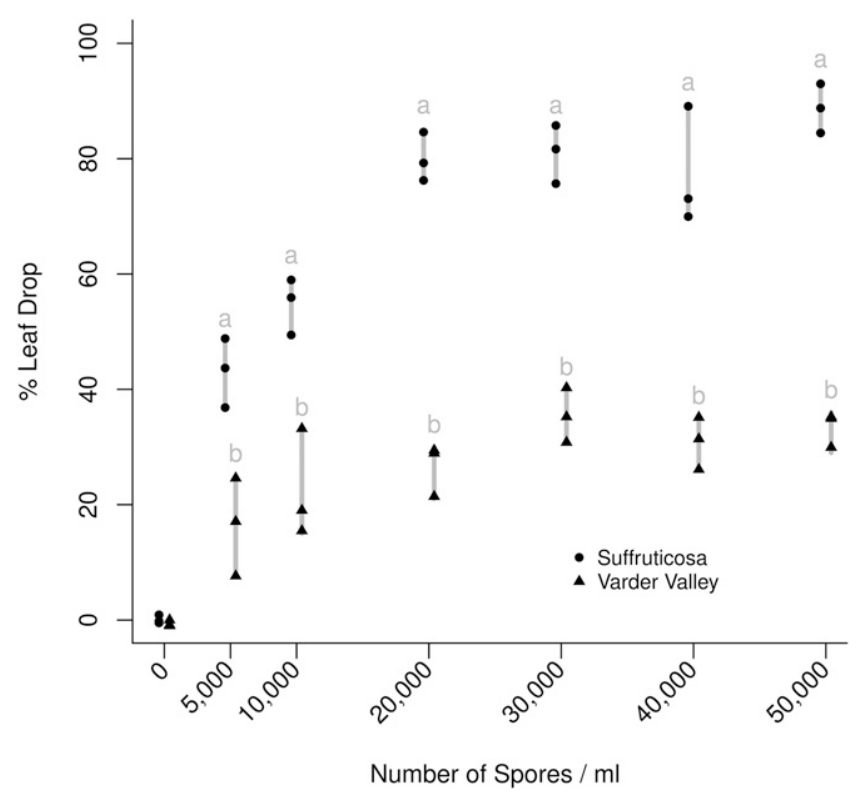

Fig. 3. Percent defoliation of detached stems of Buxus sempervirens 'Suffruticosa' and 'Vardar Valley' sprayed with increasing spore concentrations $\left(0,5 \times 10^{3}, 1 \times 10^{4}, 2 \times 10^{4}, 3 \times 10^{4}, 4 \times 10^{4}\right.$, and $5 \times 10^{4}$ spores $/ \mathrm{mL}$ ). See Figure 2 for an explanation of points, lines, and letters.

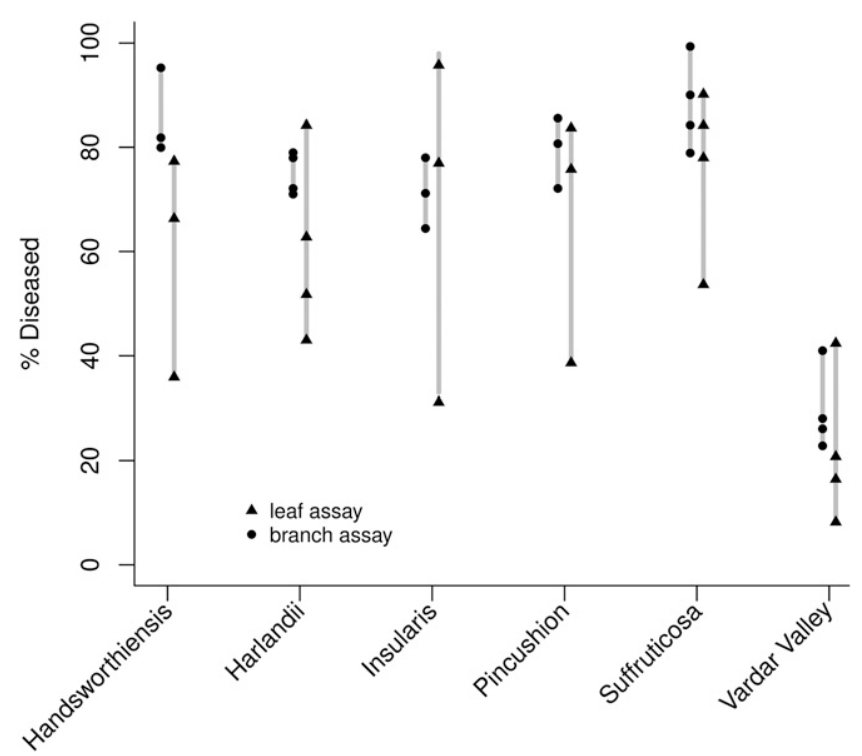

Fig. 4. Comparison of boxwood blight assay inoculation methods (leaf inoculation vs. stem spray) for six genotypes of boxwood. For leaf inoculation assay, symptoms are expressed as percent diseased leaf area; for the stem spray assay, symptoms are expressed as percent defoliation. See Figure 2 for an explanation of points and lines. 
genotypes was at $300(P<0.007)$ and $400(P<$ $0.026)$ spores per leaf. However, with percentage of diseased leaf area as the dependent variable, the genotypes differed significantly for all concentrations except zero and 100 spores (Fig. 2B). We recommend inoculating with 500 spores per leaf for leaf inoculation, where the differences were largest for percent diseased leaf area.

For the stem spray inoculation assay with the susceptible cultivar Suffruticosa, disease symptoms did not increase beyond a spray concentration of 20,000 spores $/ \mathrm{mL}(80 \%$ fallen leaves; Fig. 3). The less susceptible cultivar Vardar Valley did not have more than $40 \%$ fallen leaves at any concentration. The two genotypes differed significantly, even at the low concentration of 5000 spores $/ \mathrm{mL}$.

Comparison of the two methods (leaf inoculation vs. stem spray inoculation) revealed that both methods yield similar, although not identical, results in terms of relative susceptibility of different genotypes of boxwood (Fig. 4). Note that the variance was always larger for the leaf inoculation assay (estimated to be 2.4 times larger on the logit scale), which was taken into account when doing the analysis. There were no significant differences between the two assays for any of the cultivars tested. The correlation between assay means (on the logit scale) over cultivars was $0.82(P=0.046)$. As expected, we did see differences in symptom expression among the six cultivars tested, particularly in the apparent greater tolerance of 'Vardar Valley' to the fungus.

Both the leaf inoculation assay and the stem spray inoculation assay use detached stems. The leaf inoculation assay is advantageous in that it uses less inoculum and leaf material per assay and also allows more control over the exact number of spores inoculated onto each leaf. However, the stem spray inoculation method is better suited to quickly screening large numbers of genotypes such as a germplasm collection or seedlings from a breeding program. Also, it produces less variable results and is advantageous when using small sample sizes. We are continuing this work to correlate symptom expression on detached stems with whole-plant reactions and also to determine the effect of plant physiological state on symptom expression with the ultimate goal of developing a rapid and accurate assay to screen hundreds of genotypes for resistance to boxwood blight.

\section{Literature Cited}

Batdorf, L.R. 2004. Boxwood: An illustrated encyclopedia. The American Boxwood Society, Boyce, VA.

Batdorf, L.R. 2005. Boxwood handbook. 3rd Ed. Greater Valley Publ., Winchester, VA.

Douglas, S.M. 2012. Boxwood blight-A new disease for Connecticut and the U.S. The Connecticut Agricultural Experiment Station. 22 Aug. 2014. <http://www.ct.gov/caes/lib/ caes/documents/publications/fact_sheets/plant pathology_and_ecology/boxwood_blight-_a_ new_disease_for_connecticut_and_the_u.s. 07-20-12_r.pdf $>$.

Elmhirst, J.F. and B.E. Auxier. 2013. First report of box blight caused by Cylindrocladium pseudonaviculata (C. buxicola) in British Columbia, Canada. Plant Dis. 97:559.

Ganci, M., D.M. Benson, and K.L. Ivors. 2013. Susceptibility of commercial boxwood varieties to Cylindrocladium buxicola. NCSU Cooperative Extension. 22 Aug. 2014. http:// www.ces.ncsu.edu/wp-content/uploads/2013/05/ final-2012-cult-susc-summary.pdf.

Gehesquiere, B. 2014. Cylindrocladium buxicola nom. cons. prop. (syn. Calonectria pseudonaviculata) on Buxus: Molecular characterization, epidemiology, host resistance and fungicide control. PhD thesis, Ghent University, Ghent, Belgium.
Hagan, A.K. and K. Conner. 2013. Boxwood blight - A new disease of boxwood in the nursery and landscape in Alabama. 20 Nov. 2014. <https:// sites.aces.edu/group/timelyinfo/Documents/ 2013\%20Boxwood\%20Blight $\% 20$ TI\%20Updated. pdf $>$.

Henricot, B. and A. Culham. 2002. Cylindrocladium buxicola, a new species affecting Buxus spp., and its phylogenetic status. Mycologia 94:980-997.

Henricot, B., C. Gorton, G. Denton, and J. Denton. 2008. Studies on the control of Cylindrocladium buxicola using fungicides and host resistance. Plant Dis. 92:1273-1279.

Hothorn, T., F. Bretz, and P. Westfall. 2008. Simultaneous inference in general parametric models. Biom. J. 50:346-363.

Ivors, K.L., L.W. Lacey, D.C. Milks, S.M. Douglas, M.K. Inman, R.E. Marra, and J.A. LaMondia 2012. First report of boxwood blight caused by Cylindrocladium pseudonaviculatum in the United States. Plant Dis. 96:1070.

LaMondia, J.A. 2014. Fungicide efficacy against Calonectria pseudonaviculata, causal agent of boxwood blight. Plant Dis. 98:99-102.

Malapi-Wight, M., J.B. Hebert, R. Buckley, M.L. Daughtrey, N.F. Gregory, K. Rane, S. Tirpak, and J. Crouch. 2013. First report of boxwood blight caused by Calonectria pseudonaviculata in Delaware, Maryland, New Jersey and New York. Plant Dis. 98:698.

Pinheiro, J., D. Bates, S. DebRoy, and D. Sarkar, and R Core Team. 2014. nlme: Linear and nonlinear mixed effects models. $\mathrm{R}$ package version 3.1 117. 22 Aug. 2014. <http://CRAN.R-project.org/ package $=$ nlme $>$.

R Core Team. 2014. R: A language and environment for statistical computing. R Foundation for Statistical Computing, Vienna, Austria. 22 Aug. 2014. < http://www.R-project.org/>

USDA-NASS, 2010. Census of Horticultural Specialties (2009). 29 Aug. 2014. <http:// www.agcensus.usda.gov/Publications/2007/ Online_Highlights/Census_of_Horticulture Specialties/>.

Williams-Woodward, J.L. 2014. Boxwood blight found in Georgia-Disease alert. 20 Nov. 2014. $<$ http://plantpath.caes.uga.edu/extension/extension/ documents/GABoxwoodBlightAlertv1.pdf $>$. 